\title{
ALL STUDENTS ARE NOT CREATED EQUAL: THE INEQUITABLE COMBINATION OF PROPERTY-TAX-BASED SCHOOL FINANCE SYSTEMS AND LOCAL CONTROL
}

\author{
ERIN E. KELLY
}

\section{INTRODUCTION}

"The nation is hardly 'indivisible' where education is concerned. It is at least two nations, quite methodically divided, with ... liberty for some ... and justice... only for the kids whose parents can afford to purchase it."

Although every state constitution has an education clause that requires legislatures to educate their children, ${ }^{2}$ most states have adopted school finance schemes that disregard the rights of poor children who desperately need educational benefits. By relying principally on property taxes to generate money for education, ${ }^{3}$ the majority of school funding schemes impermissibly create wealth-based disparities in educational opportunities. Wealthy school districts raise a large amount of revenue from low tax rates, whereas poor school districts levy a much higher tax rate but generate less revenue. ${ }^{4}$ Thus, these school finance schemes enable wealthy students to attain educational luxuries while poor districts lack basic necessities. ${ }^{5}$ The inadequate education that poor stu-

1. Jonathan Kozol, Savage Inequalities: Children in AmERICA's Schools 212 (1991).

2. William E. Sparkman, The Legal Foundations of Public School Finance, 35 B.C. L. REV. 569, 572-73 (1994).

3. Most states generate a substantial portion of their educational budgets from local property taxes. See William E. Thro, The Significance of the Tennessee School Finance Decision, 85 EDUC. L. REP. 11, 11 n.2 (1993).

4. Ron Renchler, Financial Equity in the Schools, ERIC DIGEST, Dec. 1992, at 1. In some states, the unequal ability among districts to raise revenue for schools varies by a factor as high as ten to one. AlLAN ODDEN, U.S. DEP'T OF EDUC., THE CHANGING CONTOURS OF SCHOOL FINANCE 3 (1991). In this Note, "wealthy" refers to districts with a high socioeconomic status and "poor" refers to school districts with a low socioeconomic status.

5. Thro, supra note 3 , at 13 . See generally KOZOL, supra note 1 (describing the 
dents receive perpetuates and exacerbates their disadvantaged status.

State legislatures, recognizing the blatant injustice of propertytax educational funding, have made a token attempt to alleviate soine of the spending disparities by guaranteeing districts a minimum amount of state aid per pupil. ${ }^{6}$ The guaranteed minimums, however, do not adequately educate poor students. Property-tax systems also fail to alleviate fiscal inequality because wealthy districts can raise funds above the guaranteed minimums. ${ }^{7}$ The educational disparities that these school finance systems create have prompted legal challenges against the schemes on both federal and state constitutional grounds. ${ }^{8}$

Legislatures have responded to successful constitutional challenges by providing additional revenue to poor schools. Through mcreased funding, legislatures have attempted both to reduce spending variations among districts and to enrich the educational programs of poor schools. However, the revised funding formulas still fail to eliminate expenditure disparities. Moreover, although each of the revised funding schemes gives poor schools additional aid, not all of the systems have the same potential to substantively improve poor districts' educational programs. The local impact of school finance reform in Kentucky, Massachusetts, New Jersey, Tennessee, and Texas illustrates that the most effective reform measures are not limited to merely an increase in funding to poor

bleak conditions in underfunded schools).

6. Renchler, supra note 4 , at 1 . The three basic types of equalization programs are flat grants, foundation aid, and percentage equalizing. Thro, supra note 3 , at 13 n.19; National EdUc. Ass'N, U.S. DeP'T of EdUC., UNDerstanding STATE SCHOOL FINANCE FORMULAS 9-11 (1987). Flat grants provide a district with an equal number of dollars per student and faculty ineinber. Id. at 9 . Under a foundation program, the state sets a foundation amount, which is the minimum amount of money that will adequately educate each pupil. The state requires local school districts to tax at a minimum rate. The state pays the district foundation aid, which is the difference between the amount of money per student that the district raises through the mandated tax rate and the foundation amount. $I d$. at 9-10. In a percentage equalizing system, the state reimburses a proportion of local educational expenditures in imverse proportion to a district's wealth. The state calculates an aid ratio by combining wealth per pupil and the nominal state percentage of expenditures. The state applies the aid ratio to each district to determine the amount of the state contribution. Id. at 10-11. The majority of states, before and after reform, have distributed aid pursuant to foundation programs. Id. at 16.

7. Renchler, supra note 4 , at 1 .

8. Plaintiffs in $\mathbf{4 5}$ states have challenged the state constitutionality of school funding schemes. See Joshua S. Wyner, Toward a Common Law Theory of Minimal Adequacy in Public Education, 1992/1993 ANN. SURV. AM. L. 389, 397-98 (1994). 
schools. States' revised funding systems also must encourage poor districts to improve and expand upon their core curricula and implement accountability mechanisms.

Part I of this Note describes the federal and state constitutional challenges that plaintiffs have advanced against state school funding schemes. Part III then discusses the state supreme court decisions in Kentucky, Massachusetts, New Jersey, Tennessee, and Texas that imvalidated school funding systems relying principally on local property taxes to fund education. This Part also examines the legislatures' responses to these decisions and the local effects of their revised formulas. Although the new funding plans can provide poor schools with additional revenue, the revised schemes still fail to give poor districts equal access to state aid. This Note concludes that in order to effectively improve the quality of education in poor districts, school finance systems must include incentives for poor districts to expand and enrich upon their core curricula and must contain accountability mechanisms.

\section{BASES For CONSTITUTIONAL CHALlENGES to PROPERTY-TAX SCHOOL FUNDING SYSTEMS}

In the late 1960s and early 1970s, plamtiffs challenged funding disparities primarily under the Equal Protection Clause of the Constitution.' Plaintiffs contended that because education is a fundaniental right, the Fourteenth Amendment guaranteed students equality of educational funding. States allegedly violated the Fourteenth Amendinent because they failed to ensure that poor schools were as adequately funded as those in wealthy districts.

In San Antonio Independent School District v. Rodriguez, ${ }^{10}$ the United States Supreme Court foreclosed the use of the Equal Protection Clause to challenge funding disparities. The Rodriguez plaimtiffs contended that because Texas relied on property taxes to fund education, the system unconstitutionally created wealth-based disparities in educational opportunities and denied poor students their fundainental right to an education. ${ }^{11}$ However, the Rodriguez Court held that wealth was not a suspect classification and that education was not a fundaniental right. ${ }^{12}$ Wealth was not a

9. Thro, supra note 3 , at 14; see U.S. CONST. amend. XIV, \& 1.

10. 411 U.S. 1 (1973), reh'g denied, 411 U.S. 959 (1973).

11. Id. at $16-17$.

12. Id. at 18. 
suspect classification because the Court found no basis for beheving that poor students lived only in school districts with low property values. ${ }^{13}$ The Court further held that there was

no... interference with fundamental rights where only relative differences in spending levels are involved and where... no charge fairly could be inade that the system fails to provide each child with an opportunity to acquire the basic mininal skills necessary for the enjoyment of the rights of speech and of full participation in the political process. ${ }^{14}$

The Court therefore applied a rational basis test to the Texas finance systein and ruled that the state's reliance on property taxes was a rational and constitutional ineans of proinoting local control over schools. ${ }^{15}$

Although Rodriguez denies plaintiffs a federal constitutional claim, the New Jersey Suprenie Court's decision in Robinson $v$. Cahill $^{16}$ deinonstrates that plaintiffs can successfully attack discriminatory funding schemes on the state level. The New Jersey Supreine Court held that New Jersey's finance scliene violated the state constitution's education clause because the systen's reliance on property taxes to fund education created educational disparities. ${ }^{17}$ Since Robinson, other state high courts have struck down funding schentes on either state equal protection or education clause grounds. ${ }^{18}$

State equal protection claims parallel those made pursuant to the Fourteenth Amendment of the Constitution. Plaintiffs bringing

13. Id. at 22-23.

14. Id. at 37 (quoted in Wyner, supra note 8 , at 393 ).

15. Id. at $44,54-55$.

16. 303 A.2d 273 (N.J.), affd, 306 A.2d 65 (per curiam), cert. denied, 414 U.S. 976 (1973), affd on reh'g, 351 A.2d 713, 724 (N.J.), cert. denied, 423 U.S. 913 (1975).

17. Robinson, 303 A.2d at 295.

18. Eleven state supreme courts have invalidated inequitable funding scheines on state equal protection and/or education clause grounds. See DuPree v. Alma Sch. Dist. No. 30, 651 S.W.2d 90, 93 (Ark. 1983); Horton v. Meskill, 376 A.2d 359, 374 (Conn. 1977); Rose v. Council for Better Educ., Inc., 790 S.W.2d 186, 189 (Ky. 1989); McDuffy v. Secretary of Exec. Office of Educ., 615 N.E.2d 516, 553-54 (Mass. 1993); Helena Elementary Sch. Dist. No. 1 v. State, 769 P.2d 684, 690 (Mont. 1989), amended, 784 P.2d 412, 413-14 (Mont. 1990); Robinson, 303 A.2d at 295; Tennessee Small Sch. Sys. v. McWherter, 851 S.W.2d 139, 156 (Tenn. 1993); Edgewood Indep. Sch. Dist. v. Kirby, 777 S.W.2d 391, 398 (Tex. 1989); Seattle Sch. Dist. No. 1 v. State, 585 P.2d 71, 104 (Wash. 1978) (en banc); Pauley v. Kelly, 255 S.E.2d 859, 878, 884 (W. Va. 1979); Washakie County Sch. Dist. No. 1 v. Hershler, 606 P.2d 310, 333-34 (Wyo. 1980), cert. denied, 449 U.S. 824 (1980). 
state constitutional challenges contend that education is a fundamental right that the state impermissibly infringes by maintaining a funding scheme that allocates educational benefits according to wealth. To prevail under this rationale, plaintiffs inust demonstrate that education is a fundainental right and that wealth is a suspect classification or, in the alternative, that the state's funding scheine is irrational. ${ }^{19}$

Challenges based on a state's equal protection clause rarely succeed, largely because many state high courts have followed the Rodriguez holding that education is not a fundamental right and wealth is not a suspect class. Although state courts can give broader protection to imdividual rights than the Constitution provides, courts have infrequently done so in school funding cases. Of twenty-three state equal protection clause challenges, only six have prevailed. ${ }^{20}$

Plaintiffs have had more recent success, however, with state education clause challenges. Every state constitution has an education clause that imposes a duty on legislatures to provide each child with a public education. ${ }^{21}$ Since 1989 , the high courts of Montana, Kentucky, Texas, and Massachusetts have invalidated property-tax funding scheines on education clause grounds. ${ }^{22}$ In addition to emphasizing spending inequity, education clause challenges focus on the disparate quality of education that students in poor districts receive. High courts thus appropriately invalidate property-tax funding systems because these scliemes provide dis-

19. Thro, supra note 3 , at 15 .

20. The six prevailing state equal protection clause challenges are DuPree v. Alma Sch. Dist. No 30., 651 S.W.2d 90 (Ark. 1983); Serrano v. Priest, 557 P.2d 929. (Cal. 1976), cert. denied, 432 U.S. 907 (1977); Forton v. Meskill, 376 A.2d 359 (Conn. 1977); Tennessee Small Sch. Sys. v. McWherter, 851 S.W.2d 139 (Tenn. 1993); Pauley v. Kelly, 255 S.E.2d 859 (W. Va. 1979); Washakie County Sch. Dist. No. 1 v. Herschler, 606 P.2d 310 (Wyo.), cert. denied, 449 U.S. 824 (1980).

21. . Sparkman, supra note 2, at 573.

22. Thro, supra note 3, at 19; see also Rose v. Council for Better Educ., Inc., 790 S.W.2d 186 (Ky. 1989); McDuffy v. Secretary of the Exec. Office of Educ., 615 N.E.2d 516 (Mass. 1993); Helena Elementary Sch. Dist. No. 1 v. State, 769 P.2d 684 (Mont. 1989); Edgewood Indep. Sch. Dist. v. Kirby, 777 S.W.2d 391 (Tex. 1989); Seattle Sch. Dist. No. 1 of King County v. State, 585 P.2d 71 (Wash. 1978). The Tennessee Supreme Court held that the education clause mandates a minimum level of education, but ultimately fonnd that the school finance system was unconstitutional under the state equal protection clause because the property-tax scheme was irrational. Teunessee Small Sch. Sys. v. McWherter, 851 S.W.2d 139, 152, 156 (Tenn. 1993); Thro, supra note 3, at 22. 
tricts with unequal revenues and do not give poor districts a constitutionally mandated level of quahty.

\section{LEGISLATIVE RESPONSES TO THE INVALIDATION of PROPERTY-TAX FUNDING SCHEMES AND THE LOCAL EFFECTS OF REVISED SYSTEMS}

State high courts that invalidated property-tax finance systems properly held that expenditure disparities create wealth-based differences in educational opportunities. The legislative responses to these decisions have given poor districts more revenue in order to reduce spending variations and enrich the educational programs of poor districts. Some of the modified funding formulas, however, do not ensure that substantive change will occur because they do not induce curriculum improvement.

A study of local school districts' expenditures shows that although inany factors influence the effectiveness of a school funding system, there are some general ways of assessing the local ramifications of revised schemes. The first factor is the equity of the unodified school finance systems, which can be measured through three components: horizontal equity, vertical equity, and fiscal neutrality. ${ }^{23}$ The degree of a formula's horizontal equity can be observed by comparing the per pupil expenditures of the wealthiest and poorest districts. Even though absolute equality of expenditures is not possible, these new systems must substantially narrow revenue gaps to eliminate wealth-based allocations of benefits. A scheme with vertical equity takes into account the different costs associated with educating particular kinds of students, such as bilingual, special education, or gifted pupils. Finally, fiscal neutrahty requires similar tax efforts and burdens among districts. ${ }^{24}$

The second factor is whether legislative reforms encourage poor districts to improve and expand upon their core educational curricula..$^{25}$ For example, new finance schemes that have separate

23. Lawrence O. Picus \& LINDA HeRTERT, U.S. DeP'T OF Educ., A SchoOl Finance DIlemma for TeXas: ACHIEving Equity in a Time of Fiscal Constraint 3 (Working Paper No. 33, Jan. 1993).

24. NATIONAL EDUC. Ass'N, supra note 6, at 5.

25. Some reform opponents have argued that school aid has overwhelmingly flowed to teacher and administrative salaries rather than to new educational services for students. See, e.g., D.P. Moynihan, Equalizing Education: In Whose Benefit?, 29 THE PUB. INTEREST 69, 74-75 (1972). However, salary increases have value because they could improve employees' morale and encourage more qualified teachers to seek employment in low in- 
capital-outlay and maintenance-aid components can save poor districts from investing all of their new money in crumbling buildings instead of in new educational prograins. Formulas that ensure funding stability also can prompt districts to adopt new, innovative programs. Moreover, state prerequisites to aid, such as outcomebased assessment or long-range planning, promote curriculum expansion.

The third factor is whether the revised school finance schemes have accountability mechamisms, such as standardized testing and oversight committees, to ensure that districts use money effectively. Accountability mechanisms can encourage a district to bolster its curriculum in tested subject areas. In addition, they can help a district to identify areas of mismanagement and to understand how additional aid impacts student performance.

Courts' methods of invalidating funding schemes, whether on the basis of state equal protection or education clause grounds, have not appeared to influence the legislative responses to the imvalidation of funding schemes. All of the new legislative schemes attempt to give poor districts more money. Although these new systems mcrease the aniount of state aid available to poor districts, an examination of the schemes' horizontal equity, vertical equity, and fiscal neutrahty reveals that they do not all significantly narrow the revenue gap between poor and wealthy districts. Despite the modification of the formulas, wealthy districts still can raise more revenue than the state provides to poor districts.

State legislatures undoubtedly intend for poor districts to use increases in state funding to improve their educational programs. However, a study of the local effects of revised funding formulas in Kentucky, Massachusetts, New Jersey, Teimessee, and Texas shows that states cannot give local districts total discretion as to how to use new aid. Rather, revised scheines must condition new funding on substantive educational improvements to rectify the educational inadequacies in historically poor districts.

\section{A. Kentucky}

When imvalidating Kentucky's school finance plan, the Kentucky Supreme Court focused on the degree of fiscal inequity 
among districts and on the inferior quality of education that poor districts received. In Rose v. Council for Better Education Inc. ${ }^{26}$ the Kentucky Supreme Court declared that not only the state's funding formnla, but the entire school system violated the education clause of the Kentucky Constitution. The court held that the legislature had not fulfilled the education clause's mandate of providing an "efficient system of common schools" throughout the state. ${ }^{27}$

At the time Rose was decided, the state contributed funds for education under a Minimum Foundation Program (MFP) and a Percentage Equalizing Program (PEP). To receive MFP funding, districts needed to levy a minimum property tax rate. ${ }^{28}$ Each district also had to operate its schools and pay its teachers for 185 days per year. ${ }^{29}$ If districts qualified for MFP funds, the state would give districts a grant based on the district's average daily student attendance in each grade. ${ }^{30}$ The PEP element of the formula attempted to minimize disparities in wealthy and poor districts' educational expenditures. ${ }^{31}$ After determining the maximum tax rate that its PEP fund could match, the state gave poor districts the difference between what the PEP rate would produce and the amount of money that the district actually generated. ${ }^{32}$ The Kentucky Supreme Court found that the PEP rate was too low to minimize disparities. ${ }^{33}$

The court correctly found that Kentucky's system offered its poor students few educational opportunities. ${ }^{34}$ On the national level, $80 \%$ of Kentucky's school districts were "poor" in terms of taxable property, and the other $20 \%$ were below the national average. ${ }^{35}$ The poor districts had fewer course offerings, lower achievenient test scores, and higher student-teacher ratios than wealthy districts. ${ }^{36}$ Thus, the court correctly reasoned that the

26. 790 S.W.2d 186, 215 (Ky. 1989).

27. Id. at 215 .

28. Id. at 194.

29. Id. at 196.

30. Id.

31. Id.

32. Id.

33. Id. The PEP rate was a mere 13 cents for every $\$ 100$ of property valuation. Id. at $196 \mathrm{n} .10$.

34. Id. at 213 .

35. Id. at 197.

36. Id. 
scheme did not provide students with an "efficient" educational system. Unlike most other high courts, the Kentucky court enumerated the characteristics that would fulfill the constitutionally mandated standard of an "efficient" school system, ${ }^{37}$ but emphasized that the General Assembly had to decide how to achieve a constitutional education plan. ${ }^{38}$

Within eleven months of Rose, the Kentucky General Assembly enacted the Kentucky Education Reform Act of 1990 (KERA). ${ }^{39}$ KERA has three elements of reform: finance, curriculum, and governance..$^{40}$ KERA's finance reform component consists of a base funding level, Tier I, and Tier II. ${ }^{41}$ The base fundmg level is a per pupil sum adjusted by several factors that influence educational costs. ${ }^{42}$ The new system requires districts to raise a minimum Equivalent Tax Rate (ETR) of 30 cents per $\$ 100$ of assessed property value ${ }^{43}$ before districts can receive aid. The

37. The characteristics include whether the school system is 1) free to all; 2) provides equal educational opportunities for all students; 3) state controlled and administered; 4) "substantially uniform"; and 5) equal to and for all students. Id. at 212. An efficient system must aim to provide students with the following seven capabilities: 1) "oral and written communication skills" that enable them to function in a counplex and cbanging society; 2) "knowledge of economic, social, and political systems" that will permit them to make informed choices; 3) understanding of the governmental process; 4) knowledge of "mental and physical wellness"; 5) knowledge of the arts; 6) sufficient training in vocational or educational fields to enable students to choose and pursue life work; and 7) a level of educational or vocational skills that will allow students to compete favorably with students in other states, academia, and in the job narket. Id. The obligation to maintain an efficient system cannot be shifted to local districts. Id.

38. Id.

39. Kentucky Education Reform Act of 1990, ch. 476, $1990 \mathrm{Ky}$. Acts 1208 (codified as amended in scattered sections of KY. REV. STAT. ANN. \$§ 156.005-446.260 (Baldwin 1995)).

40. Jacob E. Adams, Jr., Spending School Reform Dollars in Kentucky: Familiar Patterns and New Programs, But Is This Reform?, 16 EDuc. Evaluation \& Pol'Y ANALYSIS 375, 377 (Winter 1994).

41. KY. ReV. Stat. ANN. \$§ 157.330-.440 (Baldwin 1995).

42. KY. REv. STAT. ANN. \$§ 157.320(2), 157.360 (Baldwin 1995). The state adjusts the base funding level for inflation. BETTY E. STEFFY, THE KENTUCKY EDUCATION REFORM 289 (1993). The additional cost factors are for exceptional children, transportation, and at-risk students. KY. REV. STAT. ANN. \& 157.360(2) (Baldwin 1995). The average base contribution, including the additional cost factors, was $\$ 3,084$ per pupil in 1992-1993. KENTUCKY OFFICE OF EDUCATION ACCOUNTABILITY, 1993 ANNUAL REPORT 41 (1993) [hereinafter KY OFFICE OF ACCOUNTABILITY].

43. KY OFFICE OF ACCOUNTABILITY, supra note 42, at 27; see also KY. REV. STAT. ANN. $\S 160.470(12)$ (a) (Baldwin 1995). KERA also provides that all real property subject to taxation must be assessed at $100 \%$ of fair cash value. MIKE D. RICHARDSON EI AL, U.S. DEP'T OF EDUC., AN ANALYSIS OF KERA: KENTUCKY'S ANSWER TO EDUCATION- 
state's contribution to the district is the difference between the amount of revenue the district raises through the ETR and the base funding level..$^{44}$

The Tier I element of the revised system enables districts to tax at a rate that generates additional revenue of up to $15 \%$ of the base funding level. ${ }^{45}$ Tier I funds equalize the tax increase at $150 \%$ of the statewide average. ${ }^{46}$ Tier II sets a tax ceiling at a levy that will raise up to $30 \%$ of the base funding level and Tier I funds. ${ }^{47}$ Tier $I I$ funds are not equalized by the state. ${ }^{48}$ No district, however, is required to tax at a rate lower than the one levied before KERA reform in 1989-90. ${ }^{49}$ Thus, the districts that raised revenue above the Tier II cap in 1989-90 can contimue to do so.

Despite the fact that soune of the wealthiest districts appear to be exempt froin KERA's revenue cap, the revised scheme has reduced expenditure disparities. The Tier II revenue cap lowered expenditure disparities between the average of the highest and the lowest wealth districts froin $35.87 \%$ to $16.72 \% .^{50}$ However, because the wealthiest districts are exempt from the cap, the new systein cannot narrow the gap at the ends of the expenditure spectrum. Although the scheme has a vertical equity component because it gives districts extra aid for educating special students, the amounts of the additional allotments are arbitrary. The legislature has not shown that the allotments accurately reflect the costs of educating special students.

Moreover, poor districts' immediate revenue increases may be short-lived because the new formula still impermissibly conditions revenue on a district's ability to tax. Poor districts can only "catch up" to wealthy ones by levying additional taxes to receive Tier I and Tier II aid. Tier I does not consider poor districts' unequal ability to generate revenue because it only equalizes up to $15 \%$ of

AL EQUTY 5 (1991). If a district fails to provide the minimum level of support, school board members may be removed from office. KY. REV. STAT. ANN. § 160.470(12)(b) (Baldwin 1995).

44. KY OFFICE OF ACCOUNTABIITY, supra note 42, at 28.

45. KY. REV. STAT. ANN. \& 157.440(1)(a) (Baldwin 1995).

46. Id.

47. KY. REv. STAT. ANN. \& 157.440(2) (Baldwin 1995).

48. Id; KY OFFICE OF ACCOUNTABILITY, supra note 42, at 29.

49. KY. REV. STAT. ANN. § 157.440(1)(d) (Baldwin 1995); KY OFFICE OF ACcOUNTABILITY, supra note 42 , at $29-30$.

50. KY OFFICE OF ACCOUNTABIITY, supra note 42 , at 39. 
the base funding level regardless of wealth. ${ }^{51}$ Moreover, the Tier II $30 \%$ cap generally directly affects only wealthy districts and is not equalized by the state..$^{52}$ Because Kentucky's finance scheme conditions educational aid on a district's wealth, the new system contimues to deny poor districts an equal access to revenue.

Notwithstanding the new system's fiscal pitfalls, the broadbased focus of KERA's reform has encouraged districts to invest their new funding in curriculum enrichment. KERA established the Facilities Support Program of Kentucky (FSPK), which gives districts additional aid to improve all of their educational facilities. ${ }^{53}$ In addition, KERA compels districts to spend money on new programs that have a long-term impact on educational progress, such as early childhood education, ${ }^{54}$ professional development, ${ }^{55}$ and family resources and youth services. ${ }^{56}$ Under these mandates, districts must establish curriculum frameworks, nongraded primary classes, and new teaching and learning goals. To implement these objectives, KERA has provided $\$ 17$ per pupil for staff development. $^{57}$

A study of local level expenditures for two high and low wealth Kentucky school districts shows that these KERA mandates created the desired curriculum expansion. The poor districts invested in additional personnel, instruction, facilities, and programs. ${ }^{58}$ Even though all four districts increased spending on staff development, most of the funding went toward oprogramming mstead of salary increases. ${ }^{59}$ For example, District 3 instituted a pre-school

51. KY. REv. STAT. ANN. \& 157.440(1)(a) (Baldwin 1995).

52. KY. REV. STAT. ANN. \& 157.440(2) (Baldwin 1995).

53. KY. REv. Stat. ANN. \& 157.440(1)(b) (Baldwin 1995). Like the Tier I component, the FSPK provides that if school districts levy an additional tax of 5 cents over the ETR rate, the state will equalize the tax at $150 \%$ of the average per pupil property wealth. KY OFFICE OF ACCOUNTABILTTY, supra note 42, at 46. During 1992-1993, Kentucky appropriated $\$ 13.5$ million of FSPK funds under a pro rata formula. Id.

54. KY. REV. STAT. ANN. § 157.317 (Baldwin 1995).

55. See KY. REV. StAT. ANN. $\$ 156.095$ (Baldwin 1995).

56. KY. REV. STAT. ANN. § 156.497 (Baldwin 1995).

57. Adams, supra note 40 , at 384 .

58. District 1 is a high wealth suburban district located in the northern region of the state with a per pupil expenditure of $\$ 3,183$. Id. at 378 . District 2 is a high wealth urban district located in the central part of Kentucky with a per pupil expenditure of $\$ 4,388$. Id. District 3 is a low wealth rural district with a per pupil expenditure of $\$ 2,685$ and is located in the western part of the state. Id. District 4 is also a low wealth rural district, has a per pupil expenditure of $\$ 2,708$, and is in the eastern part of Kentucky. Id.

59. Id. at 383-84. 
for at-risk children. District 4 started summer school and afterschool tutoring programs. ${ }^{60}$

In addition, the creation of the FSPK channeled aid into instructional inaterials and technology. Districts operated additional afterschool buses, purchased coinputer equipinent, and constructed new facilities. ${ }^{61}$ The current formula, however, nay discourage long-term investınents in programs and facilities because KERA does not guarantee districts funding stability. The legislature, at its discretion, can lower a district's aid allocation from that of the prior year.

However, KERA appropriately includes two accountability inechamisms that encourage substantive change. First, KERA requires statewide curriculum assessment. ${ }^{62}$ Schools must achieve threshold standardized test scores on an annual basis and will receive cash awards if, on a biennial average, they score $1 \%$ over the threshold. ${ }^{63}$ If schools score below the threshold, they are subject to sanctions that include the creation of a school improvement plan, probation of staff, or student transfer. ${ }^{64}$ This inethod of accountability is effective because, although standardized test scores inay not define precisely what a student learns, comparing scores with other districts can both help poor districts to identify problem areas and prompt districts to bolster curricula in the tested subject areas. In addition, Kentucky monitors districts through superimtendent screening committees, a task force on high school restructuring, an early childhood advisory council, and a higher education review commission. ${ }^{65}$

To fulfill the constitutional mandate set forth in Rose, the Kentucky legislature created an entirely new educational system. In addition to state aid calculation changes, KERA provides for substantial educational reform. ${ }^{66}$ These changes properly shift control away from local school boards and give the state legislature more oversight of districts' educational programs. One might

60. Id. at $385-86$.

61. Id. at 385.

62. KY. REV. STAT. ANN. $\$ 158.6453$ (Baldwin 1995). For a detailed discussion of assessment procedures, see STEFFY, supra note 42 , at 47-74.

63. KY. REv. STAT. ANN. $\$ 158.6455$ (1) (Baldwin 1995); KY OFFICE OF ACCOUNTABILITY, supra note 42 , at 78.

64. KY OFFICE OF ACCOUNTABILITY, supra note 42, at 78-79.

65. Id. at $217,291,294,296$.

66. See supra notes 53-57 and accompanying text. 
argue that Kentucky's increase of state legislative oversight will prompt an inefficient use of funds because local school boards have a greater knowledge of their schools' needs. However, the Rose court, ${ }^{67}$ like other courts that have invalidated funding schemes, emphasized that the state constitution gives the legislature the responsibility of maintaining a constitutional educational system. Legislative oversight is thus a prerequisite to a permissible finance system. The Kentucky legislature would be remiss in fulfilling its obligation if it gave local districts a free rein on how to spend education funds, especially in light of the Rose court's mandate that the new finance sclieme must provide each student with seven specific capabilities. ${ }^{68}$ Moreover, state control and accountability is necessary for taxpayer support of additional aid..$^{69}$

Furthermore, state officials who defend constitutional cliallenges to property-tax funding systems on the ground that local control promotes efficiency ironically fail to recognize that they have consistently imstituted policies that undermine local discretion. ${ }^{70}$ For example, state guidelines estabhsh uniform curriculum requirements for every public school. ${ }^{71}$ States also certify teachers on a statewide basis, and some states even standardize the use of textbooks. $^{72}$ In addition, student testing has been nationalized and failing districts are generally subject to state takeovers. ${ }^{73}$ Therefore, " $[t]$ he liberty of local districts . . . is willingly infringed on grounds of mefficiency. It is only when equal funding is the issue that the sanctity of district borders becomes absolute." ${ }^{.74}$ To ensure that additional revenue makes substantive improvements in poor school districts, state legislatures must continue to oversee educational programming.

67. 790 S.W.2d 186, 215-16 (Ky. 1989).

68. See supra note 37.

69. For example, the lack of an accountability component in California's system prompted voters to pass Proposition 98, which mandates school accountability report cards. LAWRENCE O. PICUS, U.S. DEP'T OF EDUC., AN UPDATE ON CALIFORNIA SCHOOL FINANCE 1992-1993: WhAT DOES THE FUTURE HOLD? 4-5 (1992). School report cards have made voters more receptive to reform. KRISTEN J. AMUNDSON \& CRAIG RICHARDSON, NAT'L SCHOOL BDS. ASSOC., STRAIGHT A'S: ACCOUNTABLITY, ASSESSMENT, ACHIEVEMENT 16 (1991).

70. KozOL, supra note 1 , at 211.

71. Id.

72. Id.

73. Id.

74. Id. 


\section{B. Massachusetts}

The Massachusetts Supreme Court, like Kentucky's Rose court, mvalidated its education funding scheme on education clause grounds. In McDuffy v. Secretary of the Executive Office of Education, ${ }^{75}$ the court held that the Commonwealth has a constitutional obligation to "cherish ... the public schools" students with an education. ${ }^{77}$ The Massachusetts legislature failed to fulfill that duty by implementing a finance scheme that offered students in poor school districts fewer educational opportunities than children in wealthy districts had. ${ }^{78}$

Like many other states' systems, the unconstitutional Massachusetts system primarily rehed on local property taxes to fund education. ${ }^{79}$ Although the state was supposed to contribute aid pursuant to a funding formula, it lacked funds to do so and imstead distributed inoney for schools through an appropriations process. ${ }^{80}$ Because this process provided only minimal state aid, the court held that the system did not fulfill poor students' constitutional right to an education. ${ }^{81}$

The McDuffy plaintiffs asked the court for a declaratory judgment, not for a particular remedy. ${ }^{82}$ This fact allowed the court to give the legislature discretion to determine what kind of systein would be appropriate. The court did hold that, at a minimum, the new system must enable students to possess the seven capabilities set forth by the Kentucky Supreme Court in Rose. ${ }^{83}$

Three days after the McDuffy decision, the legislature passed the Massachusetts Education Reform Act of 1993 (MERA), ${ }^{84}$

75. 615 N.E.2d 516 (Mass. 1993).

76. Id. at 527 .

77. Id. at 553-54. See generally Michael D. Weisman \& Mark A. Simonoff, McDuffy v. Secretary of the Executive Office of Education: A New Era for Public School Children in Massachusetts, BosTON B.J., Jan.-Feb. 1994, at 13 (discussing the court's analysis of the Massachusetts education clause).

78. McDuffy, 615 N.E.2d at 553-54. The defendants conceded that plaintiffs in poor districts suffered from, among other things, "inadequate teaching of basic subjects ... . ; neglected hibraries; inability to attract and retaim high quality teachers; lack of teacher training; lack of curriculum development; lack of predictable funding; administrative reductions; and inadequate guidance counseling." Id. at 553.

79. Id. at 550 .

80. Id. at 551 .

81. Id.

82. Id. at 522 .

83. See supra note 37 .

84. Act of June 18, 1993, ch. 71, 1993 Mass. Acts 159, amended by Act of June 21, 
which will not be fully funded until the year 2000. MERA instituted a new foundation budget for each district. ${ }^{85}$ The foundation budget is the total amount of money that the legislature beheves a district needs in order to fund its educational programs. The state calculates each district's budget according to the same formula. ${ }^{86}$

MERA, like Kentucky's scheme, requires a minimum local contribution to the foundation budget to receive state aid. ${ }^{87}$ The required contribution accounts for a municipality's property wealth and income level. ${ }^{88}$ Once the state determines the local inunicipality's required contribution, the state subtracts that

1995, ch. 38, 1995 Mass. Adv. Legis. Serv. 160 (Law. Co-op.).

85. See Mass. ANN. LAws ch. 70, §§ 1, 2 (Law. Co-op. Supp. 1995).

86. The formula for determining a district's foundation budget is complex. The basic elements are as follows: Fiscal year 1995 budget $=$ foundation payroll + foundation nonsalary expenses + expanded allotment program + professional development allotment + extraordiuary maintenance allotment + book and equipment allotment (BEA). MASs. ANN. LAwS ch. 70, \& 2 (Law. Co-op. Supp. 1995). The base year for calculating the foundation budget is 1993, and the foundation budget for the present year cannot exceed that of the prior year by more than $4.5 \%$. Ch. $70, \S \S 2,3$. No district that is spending above the foundation budget can reduce its spending below that level. MASS. DEP'T OF EdUC., Funding Formula Resource Materials 19 (May 1994) [hereinafter Mass. FUNDING FORMULA RESOURCE].

The state determines each element of the foundation budget by multiplying statutory fractions by the foundation enrollment. See ch. 70, $\$ 2$. The formula bases the foundation enrollment for fiscal year 1995 on the enrollment on October 1st of 1993. MASS. FUNDING FORMULA RESOURCE, supra, at 1, 20. The state breaks the foundation enrollment down into categories by grade and program (e.g., 1 teacher per 22 elementary students, 1 teacher per 15 bdingual students). See $\mathrm{ch} .70$, § 2 . The formula assumes that $3.5 \%$ of a district's pupils are special education students. $\mathrm{Ch} .70, \S 2$.

The foundation payroll (FP) is the amount of money for teacher and support staff salaries. The FP assumes specific salaries for all school personnel. For example, the FP for teachers is $\$ 38,000$ multiplied by a wage adjustment factor. Ch. $70, \S 2$.

87. MASS. ANN. Laws ch. 70, \& 2 (Law. Co-op. Supp. 1995).

88. The minimum required local contribution $=$ preliminary local contribution - overburden aid ainount - excess debt service amount. MASS. ANN. LAws ch. 70, $\$ 2$ (Law. Co-op. Supp. 1995).

A school district's required preliminary local contribution takes into account the district's prior local contribution, a mumicipal revenue growth factor, and an excess debt service amount if it was used to lower a district's minimum contribution in the prior year. Act of June 21, 1995, ch. 38, § 92, 1995 Mass. Adv. Legis. Serv. 160, 508 (Law. Co-op.) (to be codified at MASs. ANN. LAws ch. 70, § 2). The gross standard of effort for fiscal year 1994 was the amount that would have been raised by applying a tax rate of $\$ 9.40$ to the adjusted valuation of the district's property. MASs. FUNDING FORMULA RESOURCE, supra note 86 , at 13 . Districts with property values in the bottom fifth percentile and districts with a below average per capita income are allocated an overbnrden aid amount that equals the district's standard of effort gap. MASS. ANN. LAwS ch. 70, § 2 (Law. Co-op. Supp. 1995). 
amount from the foundation budget and funds the difference. The state pays its share through a combination of aid allocations. ${ }^{89}$

MERA's new finance system, however, fails to equalize expenditures among districts because it lacks horizontal equity, vertical equity, and fiscal neutrality. Although MERA provides that a district's foundation budget cannot grow by more than $4.5 \%$ over the preceding year, it does not cap the dollar amount of revenue that wealthy districts can raise. ${ }^{90}$ MERA's foundation plan thus fails to provide horizontal equity because it establishes a floor of revenue for poor districts without creating a ceiling for wealthy ones. Because the state will not fully fund the system until the year 2000, current horizontal spending inequities will imcrease.

MERA also lacks vertical equity. The formula fails to account for differences among districts when determining the districts' foundation budgets. ${ }^{91}$ For example, the formula assumes specific salaries for all personnel and that each district has a 3.5\% special education enrollment. ${ }^{92}$ The state also calculates the book and equipment allotment (BEA) regardless of a district's wealth. ${ }^{93}$ Thus, the current scheine does not give a greater priority for BEA assistance to poor districts with the most need for educational resources. MERA attempts, although unsuccessfully, to create fiscal neutrahty by accounting for a district's incoine level when determining the district's required local contribution. However, districts subject to the flat gross standard of effort rate do not have the same ability as wealthy districts to tax at this rate.

Although not a perfectly equitable systein, MERA's broad substantive educational reforms appear capable of nnproving the quality of education in poor districts. MERA encourages districts to use new funds for curriculum enrichment through MERA's

89. The different types of state aid include 1) base aid; 2) regional bonus aid; 3) foundation aid; 4) equity aid; and 5) minimum/professional development aid. MASS. ANN. LAwS ch. 70, § 2 (Law. Co-op. Supp. 1995); MASS. Funding Formula Resource, supra note 86 , at 4 . Each school district is guaranteed funding of $\$ 25$ per student, irrespective of wealth. Act of June 21, 1995, ch. 38, \& 264, 1995 Mass. Adv. Legis. Serv. 160, 576 (Law. Co-op.) (to be codified at MASS. ANN. LAwS ch. 70, $\$ 2$ ).

90. MASS. ANN. LAwS ch. 70, 33 (Law. Co-op. Supp. 1995).

91. See generally Thomas A. Downes \& Thomas F. Pogue, Adjusting School Aid Formulas For The Higher Cost Of Educating Disadvantaged Students, NAT'L TAX J., Mar. 1994, at 89 (discussing how a formula's failure to compensate for cost differentials among districts leads to inadequate state aid).

92. See MASS. ANN. LAwS ch. 70, § 2 (Law. Co-op. Supp. 1995).

93. See id. 
creation of curriculum framework committees and a new student assessment program..$^{94}$ MERA also establislied a new governance structure, whicl provides for sclool-based management and academic achievement profiles. ${ }^{95}$ Scloools that do not perform accordmg to state guidelines are subject to sanctions, which mclude the appointinent of a state "receiver" to inanage the school district."

On the local level, Massacliusetts districts lave devoted a large portion of new aid to curriculum enrichment. Several poor districts spent the bulk of their new funding to hire professional staff in order to expand their course selection. ${ }^{97}$ Districts also purcliased textbooks, new equipment, and supplies. ${ }^{98}$ For example, the Brockton scliool district, which received approximately $\$ 5.7$ million in funding, spent over $\$ 4$ million of the aid to hire professional staff. ${ }^{99}$ The Lowell school district used over $\$ 4$ million to add personnel ${ }^{100}$ and also filled seventy-seven new staff positions for five new and renovated scliools. ${ }^{101}$

MERA's stability of state aid gives districts somewhat of an incentive to invest in long-term curriculum improvements. The formula provides that a district's base aid will, at a minimum, equal the amount of the prior year. ${ }^{102}$ Because foundation enrollment for fiscal year 1995 is based on 1993 attendance figures, ${ }^{103}$ lowever, poor districts with rising enrollment may be deterred froin makmg long-term iuvestments because their per-pupil aid receipts will continually decrease.

94. MASS. DEP'T OF EDUC., EDUCATION REFORM 3RD QUARTERLY IMPLEMENTATION REPORT 2 (Spring 1994) [hereinafter 3RD QUARTERLY IMPLEMENTATION REPORT].

95. Id. at 9 .

96. Id.

97. See generally Mass. Dep'T of EDUC., THE REFoRM ACT-USE of FundS SUMMARY OF SCHOOL EXPENDITURES FOR FISCAL YEARS 1993 AND 1994 (1994) [hereinafter MASS. FUNDS 1994] (describing how districts used state funding); MASS. DEP'T OF EDUC., THE REFORM ACT-USE OF FUNDS SUMMARY OF SCHOOL EXPENDITURES FOR FISCAL YEARS 1993-1994 (1993) [hereinafter MASS. FUNDS 1993] (same). 97.

98. See generally MASS. FUNDS 1994, supra note 97; MASs. FUNDS 1993, supra note

99. MASS. FUNDS 1994, supra note 97, at 1; MASs. FUNDS 1993, supra note 97, at 1. 100. MAss. Funds 1994, supra note 97, at 2; MAss. Funds 1993, supra note 97, at 2. 101. Mass. Dep't of Educ., Education Reform Funds Making a Difference, EDUC. ToDAY, Aug. 1, 1994, at 1, 2.

102. Act of June 21, 1995, ch. 38, $\S 89,1995$ Mass. Adv. Legis. Serv. 160, 507 (Law. Co-op.) (to be codified at MASS. ANN. LAWS ch. 70, § 2).

103. See supra note 86 . 
MERA appropriately provides for accountability components to ensure that districts use aid to improve the quality of education that students receive. For example, all schools must participate in a new certification process and in professional development programs. ${ }^{104}$ The state also created an education reform implementation task force and review commission. ${ }^{105}$ It will be difficult, however, for some districts to fulfill these new mandates im light of the assumptions that the funding formula makes about the characteristics of school districts. In addition, although Massacluusetts adopted numerous mcentives to upgrade education in poor districts, the state lias not yet enacted the majority of its reform progams.

Arguably, the substantive educational improvements that MERA's state oversight provides render the system's lack of fiscal equity between poor and wealthy districts immaterial. Under this rationale, as long as the system gives poor districts a sufficient "minimum," it does not matter how much wealtlyy districts spend, especially when the McDuffy court did not explicitly require all districts to receive equal funding. However, due to the "dynamics of state politics," the amount of state aid allotments typically are determined by what wealthy school districts believe poor districts need. ${ }^{106}$ Unfortunately, legislatures have not been mclined to set the minimum aid level at an amount that would enable poor students to compete on a level with wealthy students. ${ }^{107}$ Instead, aid allotments have been geared towards enabling a poor student to hold a less-skilled job. ${ }^{108}$ Although "[t]here is a deep-seated reverence for fair play in the United States ... a and a genume distaste for loaded dice, "109 legislatures liave not truly committed themselves to leveling the educational playing field.

\section{New Jersey}

The New Jersey Supreme Court, unlike most other state high courts, lias ruled on the constitutionality of both initial and revised funding schemes. In 1975, the New Jersey Supreme Court held

104. 3RD QUARTERLY IMPLEMENTATION REPORT, supra note 94, at 12.

105. Id. at 15.

106. KozOL, supra note 1 , at 209.

107. Id.

108. See id.

109. Id. at 223. 
that the New Jersey Public School Education Act of 1975 (the Act ${ }^{110}$ was facially constitutional and that the state's education clause imposed a duty on the legislature to provide students with a "thorough and efficient" education. ${ }^{111}$ Plaintiffs successfully challenged the Act as apphied in Abbott v. Burke (Abbott I). ${ }^{112}$ The $A b b$ ott $I$ court held that the Act's finance provisions were unconstitutional because they failed to ensure that poor school districts had a "thorough and efficient" education. ${ }^{113}$ The court emphasized that the Act was only unconstitutional as apphed to poor districts. ${ }^{14}$ If the finance system granted poor students a sufficient level of revenue, then the Act wonld be constitutional even if some districts spent beyond that level. ${ }^{115}$ Thus, the ground for unconstitutionality was not funding disparity, but that the level of education in poor districts did not meet a certain threshold of quality. ${ }^{116}$ The court found that poor districts, unlike their wealthy counterparts, lacked adequate computer training, suitable facilities, science education, and foreign language programs. ${ }^{117}$ In Jersey City, for example, computer courses were taught in storage closets. ${ }^{118}$ In an East Orange middle school, teacliers taught science class in a three-foot by six-foot science area that lacked water, gas, and electrical lines. ${ }^{119}$

The Act's funding sclieme provided each district with a guaranteed tax base (GTB) of at least $134 \%$ of the state average. ${ }^{120}$ The state set a tax rate for each district at the GTB amoimt. ${ }^{121}$ If the districts generated revenue below the GTB level, the state

110. Act of Sept. 29, 1975, ch. 212, 1975 N.J. Laws 871 . The New Jersey legislature subsequently modified the Act's funding provisions when the legislature adopted the Quality Education Act of 1990. Act of July 3, 1990, ch. 52, 1990 N.J. Laws 587 (codified as amended at N.J. STAT. ANN. §§ 18A:7D-1 to 18A:66-66 (West Supp. 1995)). See infra notes $132-140$ and accompanying text.

111. Robinson v. Cahill (Robinson V), 355 A.2d 129, 132 (N.J. 1976). The Robinson V court held that New Jersey's Public School Education Act of 1975 was facially constitutional, assuming that it would be fully funded. Id. at 139.

112. 575 A.2d 359 (N.J. 1990).

113. Id. at 384 .

114. Id. at 368 .

115. Id.

116. Id.

117. Id. at 395-97.

118. Id. at 395 .

119. Id.

120. Id. at 377 .

121. Id. 
funded the difference. ${ }^{122}$ The state's share was called "equalization aid." ${ }^{23}$ The court noted that the Act did not require or assure a particular level of expenditure in any school district. ${ }^{124}$ The level of equalization aid depended completely on the GTB level and discretionary budget decisions.

Although the court recognized that equalization aid gave poor districts more money than they would have received otherwise, there were several problems with the way that the state calculated equalization aid. The flaw that most seriously hainpered poor school districts was the state's rehance on districts' budgets from the previous year as a basis for calculating the amount of equalization aid. The court held that failing to provide current-year funding created a disimcentive for districts to enrich their educational programs. ${ }^{125}$ To achieve the constitutional standard, "the totality of the [poor] districts' educational offering inust contain elements over and above those found in the affluent suburban district."126 The record showed that the need of poor urban students exceeded that of wealthy students because poor districts had higher dropout rates and lower standardized test scores. ${ }^{127}$

The Abbott I court, unlike those previously discussed, did prescribe a remedy for the legislature. First, the court held that funding must be certain every year and cannot depend on the budgeting and taxing decisions of local school boards. ${ }^{128}$ The level of funding must be enough to provide for the special needs of the poor districts. ${ }^{129}$ Although the court left the legislature discretion to create the funding mechanism itself, the court einphasized that the new system could not depend on how inuch a poor urban district was willing to tax. ${ }^{130}$ Second, the poor districts inust have a budget per pupil that is approximately equal to the average of wealthy districts plus the amount necessary to meet their special needs. ${ }^{131}$

\footnotetext{
122. Id.

123. Id.

124. Id. at 378 .

125. Id. at 379 .

126. Id. at 402 .

127. Id. at 400-02.

128. Id. at 408 .

129. Id.

130. Id. at 409 .

131. Id.
} 
Shortly after Abbott $I$, the New Jersey legislature passed the Quality of Education Act (QEA) of $1990 .{ }^{132}$ The QEA failed to pass constitutional muster in Abbott v. Burke (Abbott II). ${ }^{133}$ The QEA sought to reduce expenditure disparities between the thirty poorest "special needs districts" and the 108 wealthiest districts by the 1995-1996 school year. ${ }^{134}$ According to Abbott II, the QEA failed to reduce per pupil spending disparities between wealthy and poor districts because the QEA did not guarantee enough funding to pay for its authorized level of spending. ${ }^{135}$

The QEA adopted a foundation funding formula in an attempt to comply with the Abbott I court's mandate that aid cannot be based on a district's fiscal capacity. The QEA estabhished a Maximum Foundation Budget (MB) for each district. The computation of the $\mathrm{MB}$ gave poor districts an amount above the average per pupil expenditure in the wealthiest districts with additions for categories such as special education and vocational school. ${ }^{136}$ Since 1992, special needs districts have been able to increase their MBs through an additional special needs weight of 1.05 for each grade category. ${ }^{137}$ To qualify for state aid, a district must contrib-

132. Act of July 3, 1990, ch. 52, 1990 N.J. Laws 587 (codified as amended at N.J. STAT. ANN. §§ 18A:7D-1 to 18A:66-66 (West Supp. 1995)).

133. 643 A.2d 575, 576 (N.J. 1994).

134. William A. Firestone et al., New Jersey's Quality Education Act: Fiscal, Programmatic, Curricular and Intergovernmental Effects 2 (Apr. 1994) (symposium presentation at the annual meeting of the American Educational Research Association) (on file with author). The legislature denominated the poorest 30 districts as special need districts (SNDs). Abbott II, 643 A.2d at 576.

135. The Abbott II court noted that while the QEA contains a commitment to parity, special needs districts were only spending $84 \%$ of wealthy district expenditures. Abbott II, 643 A.2d at 576-77. Before the QEA, this figure was at least $70 \%$. Id. Although the QEA raised an additional $\$ 800$ nnillion for education through income and sales tax increases, poor districts received only $\$ 257$ million. Firestone et al., supra note 134 , at 5-6. The state primarily directed the remainder at property tax relief. William A. Firestone et al., Where Did the $\$ 800$ Million Go? The First Year of New Jersey's Quality Education Act, 16 Educ. EVAlUation \& POL'Y ANALYSIS 359, 360 (1994).

136. The formula for a district's $M B=(F \times U)+C$. N.J. STAT. ANN. § 18A:7D-6 (West Supp. 1995). $F=$ the state foundation amount; $U=$ the number of foundation aid umits for pupils in the district; and $C=$ the facilities component. \& 18A:7D-6. Simce the 1991-92 school year, $F$ has equalled $\$ 6,640$ per pupil, and $C$ has equalled $\$ 107.00$ per pupil. $\S 18 \mathrm{~A}: 7 \mathrm{D}-6(\mathrm{~b}) . \mathrm{U}$ is determined by adding the products obtamed by multiplying the number of students im particular grade and program categories by set foundation weights ranging from .5 to 1.33 . § 18A:7D-6(a). The Abbott II court emphasized that the state calculated these weights imeffectively because the state had not studied the actual costs of providing services for at-risk pupils. Abbott II, 643 A.2d at 578-79.

137. N.J. STAT. ANN. § 18A:7D-6(a) (West Supp. 1995). 
ute its "fair share," which is determined by using equalized property valuations and personal income. ${ }^{138}$ The amount of state foundation aid to a district is the difference between a district's $\mathrm{MB}$ and its local fair share. ${ }^{139}$

To proinote equity, the QEA instituted yearly spending caps on budget increases that were separate from the MB. The permissible annual cap increases for special needs districts were higher than the ones for wealthy districts. ${ }^{140}$ Equity was not guaranteed, however, because the state did not require poor districts to spend up to the cap. ${ }^{141}$ The Abbott $I I$ court held that another flaw in the QEA's design was the absence of a link between the spending cap and the MB. ${ }^{142}$ Without a nexus between the cap and the $M B$, the calculation of the cap yielded a different budget amount than the computation of the MB. Thus, a gap existed between what was needed to achieve parity between poor and wealthy districts and the amount of money that the state provided through the foundation budget. ${ }^{143}$

Due to probleins with the QEA's spending cap design, the court determined that the only way to achieve equity under the current formula was to increase the special needs weight under the $\mathrm{MB}$. However, the legislature had total discretion when determining the special needs weight. Because the mode of achieving parity under the QEA was discretionary, the QEA did not comply with Abbott I's inandate of funding certainty. ${ }^{144}$ The Abbott II court held that equal funding does not gnarantee equality of education, "[b]ut it is nonetheless clear that there is a significant connection between the sums expended and the quality of the educational opportunity." 145 Altlough the court in Abbott $I$ held that the legislature only had to provide poor districts with a sufficient floor of

138. N.̦. STAT. ANN. § 18A:7D-7 (West Supp. 1995); BETH D. BADER, U.S. DEP'T of EDUC., ABBotT v. BURKE vs. NEW JeRSEY: POLICY, POLITICS AND POLITICAL ECONOMY 22 (1991).

139. N.J. STAT. ANN. § 18A:7D-4 (West Supp. 1995).

140. Firestone et al., supra note 134, at 6 .

141. Abbott $I l, 643$ A.2d at 577-78.

142. The court noted that the Department of Education did uot even calculate what the equity spending caps were for the 1993-94 school year. Id. at 578 .

143. Id.

144. Id.

145. Id. at 580 (quoting Robinson v. Cahill (Robinson D), 303 A.2d 273, 277 (N.J. 1973)). 
revenue, the Abbott $I I$ court switched gears and primarily focused on spending disparities between poor and wealthy districts.

The Abbott II court properly held that the QEA is not an equitable finance system. Although the QEA improves the degree of horizontal equity among students by reducing disparities from $30 \%$ to $16 \%$, the QEA falls short of the court's mandate to provide "substantially equal" educational funding. ${ }^{146}$ Because the QEA's budget spending cap is not linked to the foundation formula, it cannot equalize expenditures. Nor does the scheme provide for vertical equity. The court appropriately noted that the legislature determined the amonnts of the additional weightings without empirical data about the actual costs of educating students. ${ }^{147}$

New Jersey's QEA formula, however, does promote fiscal neutrahty. The fair share component accounts for each district's income level so that the tax burdens will be equitably distributed. Although the fair share element promotes neutrality, a district's ability to raise revenue for education is still heavily dependent on its property wealth because the QEA madequately funds necessary reform.

Despite the formula's failure to provide equity, a study of ten local school districts' use of additional funding during the QEA's first year illustrates that the QEA does encourage poor districts to expand their core curricula. ${ }^{148}$ The QEA requires each special needs district (SND) to develop and submit an Education Improvement Plan (EIP) to the state that imcorporates recommendations made by external review teams. ${ }^{149}$ "The EIPs identified educational goals for each district, strategies for achieving these

146. Id. A study of the QEA's horizontal equity showed that it closed the spending gap among special needs districts to a greater degree than it closed the disparity between wealthy and special needs districts. See Firestone, et al., supra note 135, at 363.

147. The element of arbitrariness that exists for the additional weights is not unique to New Jersey's scheme. None of the states with foundation formulas appear to have formulated them pursuant to empirical data.

148. The districts in the study were divided into three categories: five special-needs districts, two foundation-aid districts, and three transition-aid districts. Firestone et al., supra note 135 , at 363-64. Special-needs districts received the most state aid under the new finance system. Id. Foundation-aid districts received a moderate amount of additional aid. Id. at 365 . Transition-aid districts were generally wealthy districts that received the smallest state-aid increase. Id.

149. Id. at 360; N.J. STAT. ANN. § 18A:7D-32 (West Supp. 1995). 
goals, and ways new QEA dollars would be used to implement the strategies." 150

The school district study revealed that the SNDs received an additional $\$ 534$ to $\$ 1,549$ per pupil. ${ }^{151}$ They spent nearly half of the new revenue on instruction and student services. ${ }^{152}$ Three of the five SNDs used aid to increase their staff or reinstate programs that the SNDs previously cut. ${ }^{153}$ Although SNDs did not spend money on additional inaterials and resources, QEA funds helped to equalize their availability. ${ }^{154}$ Four of the SNDs invested in facilities by building new structures, refurbishing buildimgs, and installing laboratories. ${ }^{155}$

Moreover, the QEA's long-range planning requirement encouraged poor districts to improve and expand course offerings. Districts created health and social service programs, weekend and summer school programs, extracurricular activities, and early childhood education programs. ${ }^{156}$ The districts also added elective course offerings such as home economics, industrial education, and Advanced Placement classes. ${ }^{157}$ Special needs districts have reported that the QEA's oversight influenced their decisions about how to use resources. ${ }^{158}$

In addition to imitiating curriculum expansion, the QEA system has an accountability component that encourages districts to use QEA funding responsibly and to invest in curriculum improveinents. Each district's EIP plan lias to "identify, price, and justify" expenditures to the state. ${ }^{159}$ The QEA, however, lacks a inechanism that can ineasure how additional funds given to SNDs im1prove educational quality. Although test scores inay provide an indirect nieasurement of the quality of education in poor districts, the tests are not given at each grade level and have a narrow scope. ${ }^{160}$

150. Firestone et al., supra note 135 , at 360 .

151. Id. at 363 .

152. Id. at 365 .

153. Id. at 366 .

154. Id.

155. Id. at 367.

156. Id.

157. Id.

158. Firestone et al., supra note 134 , at $37-38$.

159. Firestone et al., supra note 135, at 370; N.J. STAT. ANN. § 18A:7D-32 (West Supp. 1995).

160. The state only tests studeuts in grades three, six, and nine. Firestone et al., supra note 135 , at 370 . 
Curriculum expansion in poor districts could be hampered by the uncertainty of the QEA's status and funding. The Abbott II court's invalidation of the QEA will force the legislature to revise its fiscal system. In addition, pohtical haggling has prevented the New Jersey legislature from setting state aid figures for forthcommg years. ${ }^{161}$ Until these issues are resolved, districts may be reluctant to invest in programs that have long-term expenses.

School reform critics argue that revised systems only inarginally improve the quality of education in poor districts while impermissibly making drastic cuts in wealthy districts' programs. Thus, critics contend that the net effect of reform is an overall "leveling down" of educational quality throughout the state. However, the local effects of QEA reform demonstrate that this fear did not materialize. Wealthy districts did not make any substantial curriculum reductions. They ouly had to make minor cuts in educational services, "which resulted as much from residents' unwillingness to tax themselves to the level allowed by the state as from reduced state funds." 162 Furthermore, the QEA actually gave wealthy districts increases in state aid ranging from $5 \%$ to $27 \%$. ${ }^{163}$ Thus, in the QEA's first year, the finance reforms did not appear to denigrate educational prograins in wealthy districts.

Although the New Jersey legislature has not yet responded to the Abbott II decision, Abbott II's impact undoubtedly will be a funding increase to poor districts to remedy the QEA's improper preservation of expenditure disparities. If the new system retains the QEA's curriculum expansion and improvement initiatives, New Jersey's poor schools will make additional strides toward educational equality.

\section{Tennessee}

The Tennessee Suprenie Court, unlike the Kentucky, Massachusetts, and New Jersey courts, used state equal protection grounds to invalidate Tennessee's school funding scheme. In Tennessee Small School Systems v. McWherter, ${ }^{164}$ the Termessee Supreme Court held that the state's school finance systein, which

161. Id.

162. Id. at 359.

163. Id. at $364,368$.

164. 851 S.W.2d 139 (Tenn. 1993). 
relied heavily on local property taxes, created spending disparities anong scliool districts. ${ }^{165}$ The court found that the state's funding sclieme created a wealth-based classification of similarly situated students and was unconstitutional because the system lacked even a rational basis. ${ }^{166}$

At the time of McWherter, the largest source of state funding was the Temessee Foundation Program (TFP). ${ }^{167}$ The TFP was a standard foundation formula that allocated aid based on the number of students in average daily attendance, weighted by additional cost factors such as grade level, vocational courses, and special education. ${ }^{168}$ Districts that were unable to raise the foundation amount received equalization aid to make up the difference. ${ }^{169}$ The court found, however, that the TFP's equalization element coinprised only a sinall portion of total state aid and was inadequately funded. ${ }^{170}$

The record established that the TFP did not provide poor districts with enough funding to maintam an adequate educational system. Schools im poor districts lacked adequate facilities, textbooks, functioning libraries, and the funds to implement statemandated art and music classes. ${ }^{171}$ Poor districts had substantially fewer educational opportunities than wealthy districts. ${ }^{172}$ For example, im a Hancock County school, a so-called "library" consisted of "only one bookcase nestled in a room containing empty boxes, surplus furniture, a desktop copier, kitchen supplies, a bottle of mouthwash, and a popcorn machine."173

The McWherter court rejected the state's contention that the system was rationally related to a legitimate state purpose of promoting local control over schools. ${ }^{174}$ The court noted that the

165. Id at 143-147. The court noted that in 1988-89, per classroom spending varied frown $\$ 110,727$ in Kingsport to $\$ 49,167$ in Lewis County. Id. at 143 . Per pupil spending among districts ranged from $\$ 3,669$ to $\$ 1,823$. Id.

166. Id. at $152-57$.

167. Id at 143. The other sources of state funding were categorical grants that the state distributed irrespective of a district's wealth. $I d$.

168. Id.

169. Id.

170. Id. Tennessee had less than $\$ 60$ million available for equalization aid out of a $\$ 2.5$ billion education budget. Id. The court also noted that the equalization element of the TFP benefited wealthier districts because it made upward adjustments in aid for those with highly experienced and tramed teachers. Id.

171. Id. at 145 .

172. Id at 154 .

173. Id at 145 .

174. The Tennessee court thus did not adopt the U.S. Suprenne Court's rationale in 
goal of local inanagement did not justify disparities in educational opportunities. ${ }^{175}$ The court enphasized that a systein that provides for greater equalization of funds actually promotes local control because equalization gives poor districts inore educational choices. ${ }^{176}$

Unlike the New Jersey court, the McWherter court did not suggest a legislative remedy. The $M c$ Wherter court's only mandate was that the legislature estabhish a public school systein that provides substantially equal educational opportunities to all Tennessee students. ${ }^{177}$ The court emphasized that the key issues were quality and equality of education, not merely equality of funding. ${ }^{178}$

After the McWherter decision, the Tennessee General Asseinbly enacted the Education Improvement Act of 1991 (EIA). ${ }^{179}$ Like Kentucky's KERA program, Tennessee's EIA makes broad revisions in the state's entire educational system. The EIA devotes more than half of Tennessee's general fund budget to education. ${ }^{180}$ The state distributes the majority of these funds through a new percentage equalizing scheme called the Basic Education Program (BEP). ${ }^{181}$ Under this system, the Tennessee Department of Education establishes a budget for each district by organizing the educational costs of students into classroom and nonclassrooin coinponents. ${ }^{182}$ The BEP creates a funding level for each component based on the number and type of students (e.g., students on free/reduced lunch) in each district. The state's share of the costs of the BEP, which is expected to be fully funded by July of 1997, is $75 \%$ of the classroom components and $50 \%$ of the non-class-

Rodriguez that a system that relies heavily on local property taxes to fund education is rationally related to a legitimate state purpose of promoting local control over schools. See supra note 15 and accompanying text.

175. McWherter, 851 S.W.2d at 154.

176. Id.

177. Id. at 156 .

178. Id.

179. Act of Mar. 11, 1992, cl. 535, 1992 Tenn. Pub. Acts 19 (codified as amended at TENN. Code ANn. Titles 8, 49 (Supp. 1995)).

180. Tenn. State Dep't of Educ., State Finance of Public Schools in TenNESSEE 1 (no date) (on file with author).

181. TENN. CODE ANN. § 49-3-351(a) (Supp. 1995).

182. TENN. STATE DeP'T OF EDUC, supra note 180, at app. C. Classroom components imclude regular, special, and vocational education, art and music courses, principals, nurses, librarians, and substitute teachers. Id. at app. E. Nonclassroom components consist of, among other things, staff benefits and insurance, noninstructional equipment, transportation, secretarial support, and maintenance. Id. at app. C. 
room components. ${ }^{183}$ The counties collectively fund the remaining $25 \%$ of the classroom components and $50 \%$ of the non-classroom components. ${ }^{184}$ The state determines a district's individual share through a fiscal capacity index that represents a district's ability to fund education from its own taxable sources. ${ }^{185}$ To receive state aid, each county must fund its fiscal capacity index for both the classroom and nonclassrooin components. ${ }^{186}$

Unlike the Massachusetts court, the McWherter court focused on districts' expenditure disparities in holding that the Tennessee scheme was unconstitutional. The finance eleinent of the new $\mathrm{BEP}$, however, fails to equalize spending among districts. If the BEP is fully funded by 1997 , there still will be an estimated $36 \%$ disparity between the wealthy and poor districts in the 95th and 5th percentiles. ${ }^{187}$ This disparity is twice as great as the one that exists under the New Jersey and Kentucky schemes.

Because the BEP recognizes the costs of educating different types of students, it has a degree of vertical equity. In addition, the BEP is nore fiscally neutral than the New Jersey, Massachusetts, and Kentucky schemes. When determining a county's individual share of education costs, the BEP not only provides for incoine differences among districts but also accounts for a county's resident tax burdens. ${ }^{188}$ The state also bases the calculation of a

183. TENN. CODE ANN. $\S \S 49-3-354(i), 49-3-356$ (Supp. 1995). The state funds EIA reforms through a half-ceut increase in the state sales tax. GOVERNOR NED MCWherTER, TENN. DEP'T OF EDUC., TENNESSEE: THE TICKET TO TOMORROW 2 (July 1993).

184. TEnn. Code ANn. \$49-3-356 (Supp. 1995); Harry A. GReEn, Tenn. Advisory COMM'N ON INTERGOVERNMENTAL REL., FISCAL EQUALIZATION OF THE BASIC EDUCATION PROGRAM 1 (Apr. 1994).

185. TENN. AdVisory COMm'N ON INTERgovernmental ReL., LoCal Fiscal CAPACTTY FOR FUNDING EDUCATION IN TENNESSEE 9 (July 1994). Fiscal capacity is determined by five measurements: "fiscal effort, tax capacity based on property and sales, ability to pay based on per capita income, [resident] tax burden, and service responsibility based on school population as a percent of total population." Id. The formula is based on a three-year moving average of the data used, which means that the oldest year of data is dropped and the current year of data is added. Id. at 10.

186. For example, if total statewide BEP classroom funding is $\$ 500$ million, then a district with a fiscal capacity index of $1.25 \%$ would have a required local share of $\$ 6.25$ million $(\$ 500,000,000 \times 1.25 \%=\$ 6,250,000)$. Id. at 47 . If total statewide BEP nonclassrooin funding is $\$ 400$ million, then the county would have a required local share of $\$ 5$ million $(\$ 400,000,000 \times 1.25 \%=\$ 5,000,000)$. Id. Fiscal capacity indexes iu fiscal year 1995 ranged from $.03 \%$ to $20.83 \%$. Id. at $32-34$.

187. GREEN, supra note 184, at 3.

188. TENN. ADVISORY COMM'N ON INTERGOVERNMENTAL REL, supra note 185, at 9. 
county's minimum contribution on a three-year moving average to help ensure accuracy. ${ }^{189}$ However, the BEP has drawbacks for local districts. Unlike the foundation formula schemes in other states, the BEP requires local districts to fund a portion of the state's total education costs, not just a part of the district's own needs. ${ }^{190}$ Districts thus have to pay for the expenses of other school systems. As the state moves toward full funding of the BEP, the districts' share of costs also will increase, even if districts are not adding new services or experiencing enrollment growth.

Teunessee's EIA, like Kentucky and New Jersey's systeins, appropriately requires local districts to expand and enrich curriculum offerings. Every new dollar generated by the EIA must be earmarked for education; none of it can be used to imcrease salaries. ${ }^{191}$ Districts must spend at least 76 cents of each dollar on classrooin improvements such as new teachers, textbooks, and instructional technology. ${ }^{192}$ Districts can spend the remaining 24 cents on items such as utilities, transportation, and maintenance. ${ }^{193}$ Although the EIA gives local districts inuch less discretion than any other state, a high level of state oversight can increase the pubhic's acceptance of the plan and create a closer nexus between new aid and educational equality. ${ }^{194}$

Because the BEP is a percentage equalizing system, Temessee provides districts with a greater amount of funding stability than states with foundation funding prograrns. Foundation funding schemes have placed a legislative "ceiling" on the amount of per pupil aid based on the number of students in attendance during prior years. In contrast, a percentage equalizing system bases the state contribution on a percentage of a districts' total costs. This system gives districts a greater incentive to expand upon their programs because they may be able to recoup a greater portion of their expenses.

The curriculum enrichment effects of the new funding system can be observed at the local school district level. In Carter Coun-

189. Id. at 10.

190. See id. at 24.

191. MCWHERTER, supra note 183, at 4. Banning salary increases for teachers can be problematic, however, because offering a lucrative salary can be an effective means of recruitment.

192. Id.

193. Id.

194. See discussion supra note 69 and accompanying text. 
ty, schools spent $\$ 250,000$ to update textbooks for each grade. ${ }^{195}$ One high school built a fully equipped computer lab. ${ }^{196}$ The addition of the lab prompted new courses in word processing, databases, and spreadsheets. ${ }^{197}$ In Warren County, schools added Japanese, Spanish, French, and Latin courses. ${ }^{198}$ Jefferson County schools added twelve new teachers to reduce class sizes. ${ }^{199}$ They also purchased computer equipment and supplies for vocational courses. ${ }^{200}$ Under the new funding systein, the aniount of money spent on new textbooks, materials, and supplies increased by more than $200 \%$ from 1992 levels to a total of nearly $\$ 30$ million. ${ }^{201}$ Through additional capital outlay and teclinology allotments, school systems spent over $\$ 6.5$ million on capital improvements and more than $\$ 86$ million on new technologies in 1993-94. ${ }^{202}$

Furthermore, the EIA properly has raised academic standards by increasing core curriculum requirements and mandating the availability of kindergarten. ${ }^{203}$ All high scliools must implement a two-track curriculum: one for college bound students and one for those entering the work force. ${ }^{204}$ The state also requires high scliools to create objectives for each student that mclude communication, critical thinking, and problem-solving goals. ${ }^{205}$ These new requirements will stimulate expansion of scliools' core curricula and diversify elective offerings.

The EIA also lias new accountability mitiatives that proniote curriculum additions. The Teumessee Departinent of Education establislied a new standardized testing program called the Tennessee Value-Added Assessinent Systen (TVAAS). ${ }^{206}$ The TVAAS ascertanis how much Tennessee students are learning in each subject area in comparison to national averages. ${ }^{207}$ In addition,

195. MCWHERTER, supra note 183 , at 5 .

196. Id.

197. Id.

198. Id, at 6 .

199. Id, at 7 .

200. Id.

201. WAyne Qualls, TenN. STATE DeP'T of Educ., Status Report on THE IMPLementation of THE 21ST CENTURY Schools PRogram 3 (Apr. 1994).

202. Id.

203. TENN. CODE ANN. § 49-6-201(c) (Supp. 1995).

204. TENN. CODE ANN. \& 49-1-212(a) (Supp. 1995).

205. TEnN. State BD. of Educ., High School Policy: A NeW Vision for TenNESSEE HIGH SCHOOLS 4, 6 (Nov. 1993).

206. TENN. CODE ANN. §§ 49-1-601-10 (Supp. 1995).

207. Tenn. Code ANN. \& 49-1-601(b) (Supp. 1995); William A. Sanders \& SaN- 
schools must meet five different performance goals by the year $2000{ }^{208}$ The state distributes annual report cards summarizing the progress that districts make toward these goals. ${ }^{209}$ Districts can use TVAAS scores and report card data to assess how new programs influence student achievement. Thus, although the Tennessee system does not substantially narrow the gap between wealthy and poor districts' expenditures, the system's emphasis on innproving the quality of poor districts' curricula will help poor districts attain educational equality.

\section{E. Texas}

Texas, like New Jersey, has endured extensive school finance litigation. The original Texas system operated under a foundation funding program. The foundation program had a two-tiered level of funding. ${ }^{210}$ The first tier guaranteed districts a base level of funding per student in average daily attendance. ${ }^{211}$ The state encouraged districts but did not require them to generate a minimum "fair share" before receiving tier I funds. ${ }^{212}$ The second tier had an equalization component designed to supplement a district's basic tier I allotment. ${ }^{213}$ At the second tier, the state guaranteed districts a certain amount of revenue for each cent of tax effort over tier I's encouraged fair share. ${ }^{214}$ The state funded the difference between the guaranteed amount and the revenue that the tax effort collected. ${ }^{215}$

The Texas legislature responded to a constitutional challenge to the system by passing House Bill 72 (HB 72), which contributed

DRA Horn, THE UNI. OF TENN., AN OVERVIEW of tHe TenNessee VAlue-AdDed ASSESSMENT SYSTEM (TVAAS) (no date) (on file with author).

208. For example, schools should have a $95 \%$ attendance rate in grades $\mathrm{K}-6$, and a $93 \%$ attendance rate in grades $7-12$ by the year 2000 . NED MCWHERTER \& WAYNE Qualls, TenN. State Dep'T of Educ., 21st Century Schools Report Card 1 (Oct. 1994).

209. Ned McWherter \& Wayne Qualls, Tenn. State Dep't of Educ., State of the ART Classrooms that DEMAND ACCOUNTABILITY 1 (Oct. 1994).

210. Edgewood Indep. Sch. Dist. v. Kirby (Edgewood II), 804 S.W.2d 491, 495 (Tex. 1991).

211. Id.

212. Carrollton-Farmers Branch Indep. Sch. Dist. v. Edgewood Indep. Sch. Dist. (Edgewood III), 826 S.W.2d 489, 498 (Tex. 1992).

213. Edgewood II, 804 S.W.2d at 495 .

214. Id.

215. Id. 
more money to the foundation funding formula and entitled districts that met certain wealth and effort criteria to an additional enrichment equalization allotment. ${ }^{216}$ Although $\mathrm{HB} 72$ increased funding for poor districts, the Texas Supreme Court invahidated this scheme in Edgewood Independent School District v. Kirby (Edgewood I). ${ }^{217}$ The Edgewood I court found that a substantial disparity existed in districts' ability to raise revenue. ${ }^{218}$ The court noted that although the foundation program atteinpted to ensure that all districts had a minimum floor of revenue, the state inadequately funded the program and did not even cover the costs of meeting state-1nandated educational requirements. ${ }^{219}$

The Texas legislature subsequently passed Senate Bill 1 (SB 1) in $1990 .{ }^{220} \mathrm{SB} 1$ required local districts to tax at a minimuin rate before receiving tier I aid. ${ }^{221}$ SB 1 also contained incentives for districts to set tax rates above the minimum level to maximize funding under tiers $\mathrm{I}$ and $\mathrm{II}^{222}$ Despite these changes, in Edgewood II, the Texas Supreme Court held that SB 1 was unconstitutional because it distributed funds under essentially the same inefficient foundation systen that existed in Edgewood $I^{223}$ The Edgewood II court found that merely producing a more equitable system did not correct the educational "opportunity gaps" that still existed between wealthy and poor districts. 224

The Texas legislature's third attempt at creating a permissible system resulted in the passage of Senate Bill 351 (SB 351) in $1991 .{ }^{225}$ SB 351 redefined the two-tiered structure of the founda-

216. Act of July 13,1984 , ch. 28, 1984 Tex. Gen. Laws 117, amended by Act of May 30, 1995, ch. 260, 1995 Tex. Sess. Law Serv. 2207 (Vernon); UnIV. OF TEXAS \& TExAS CENTER For Educ. REs., A DECAdE OF CHANGE: PUBlic EdUCATION ACTION REFORM IN TEXAS 1981-1992, at 65-66 (Feb. 1993) [hereinafter A DECADE OF CHANGE].

217. 777 S.W.2d 391, 397 (Tex. 1989).

218. The amount of property wealth per student in the wealthiest and poorest districts showed a disparity as high as 700 to 1 . Id. at 392 . Spending per student ranged from $\$ 19,333$ to $\$ 2,112$. Id.

219. Id.

220. Act of June 7, 1990, ch. 1, 1990 Tex. Gen. Laws 1, amended by Act of May 30, 1995, ch. 260, 1995 Tex. Sess. Law Serv. 2207 (Vernon); TERRY WHITNEY \& AMY Hightower, U.S. DEP'T OF EDUC., STATE LEGISLATIVE REPORT: LESSONS IN SCHOOL FUNDING 1, at 4 (Feb. 1992).

221. Edgewood II, 804 S.W.2d 491, 495 (Tex. 1991).

222. Id.

223. Id.

224. Id. at 496.

225. Act of Apr. 15, 1991, ch. 20, 1991 Tex. Gen. Laws 381, amended by Act of June

7, 1991, ch. 391, 1991 Tex. Gen. Laws 1475, amended by Act of May 30, 1995, ch. 260, 
tion program. ${ }^{226}$ In an attempt to equalize taxation efforts within each county, ${ }^{227}$ SB 351 created County Education Districts (CEDs) that levied and collected taxes. ${ }^{228}$ The school finance system also set a cap on the rate that districts could tax. ${ }^{229}$ However, the Texas Supreme Court held that SB 351 was unconstitutional in Edgewood III. The court found that the CED tax system impermissibly created a statewide income tax. ${ }^{230}$

The Texas Supreme Court recently ruled that the Texas legislature, on its fourth attempt, successfully created a constitutional system $^{231}$.with the passage of Senate Bill 7 (SB 7). ${ }^{232}$ SB 7 set a cap of $\$ 280,000$ on the amount of taxable property value a district may have per student. ${ }^{233}$ Districts that have wealth per student in excess of $\$ 280,000$ can choose from among five options to reduce their wealth. ${ }^{234}$ Options that do not require voter approv-

1995 Tex. Sess. Law Serv. 2207 (Vernon).

226. A DECADE OF CHANGE, supra note 216 , at 72.

227. WHITNEY \& HIGHTOWER, supra note 220 , at 2.

228. PICUS \& HERTERT, supra note 23, at 2.

229. Edgewood III, 826 S.W.2d 489, 499 (Tex. 1992).

230. Texas is one of only seven states that prohibits a state income tax. WHITNEY \& HIGHTOWER, supra note 220, at 2; TEX. CONST. art. VIII, \& 1-e. The court noted that the legislature set a de facto tax rate for the CEDs when it mandated a minimum local share for tier I funding. Edgewood III, 826 S.W.2d at 501. Taxpayers had a right to vote on local tax rates for schools. By consolidating taxpayers into large CEDs, SB 351 made citizens pay a state mandated tax rate for schools over which they had no control. Id. at 509-10, 514.

231. Edgewood Indep. Sch. Dist. v. Meno (Edgewood $M$ ), 893 S.W.2d 450, 484 (Tex. 1995).

232. Act of May 31, 1993, ch. 347, 1993 Tex. Gen. Laws 1479, amended by Act of May 30, 1995, ch. 260, 1995 Tex. Sess. Law Serv. 2207 (Vernon). The Texas legislature has recently recodified portions of SB 7's provisions under different section numbers. See Act of May 30, 1995, ch. 260, 1995 Tex. Sess. Law Serv. 2207 (Vernon). For clarity, this Note continues to refer to the new Texas scheme as SB 7 because the Texas legislature retained inany of SB 7's provisions.

233. SB 7 Summarized, TEXAS EDuc. News, May 31,1993 , at 1,2 . The $\$ 280,000$ cap is referred to as the equalized wealth level. Act of May 30, 1995, ch. 260, sec. 1, $\S 41.002$ (a), 1995 Tex. Sess. Law Serv. 2207, 2384 (Vernon) (to be codified at TEx. EDUC. CODE ANN. \& 41.002(a)). SB 7 eliminated SB 351's property tax rate cap. Edgewood $I V, 893$ S.W.2d at $481-82$.

234. SB 7 Summarized, supra note 233 , at 1 ; Act of May 30, 1995, ch. 260 , sec. 1 , $\S 41.003,1995$ Tex. Sess. Law Serv. 2207, 2385 (Vernon) (to be codified at TEX. EDUC. CODE ANN. § 41.003). When SB 7 was adopted, 109 school districts had property wealth per student in excess of $\$ 280,000$. SB 7 Summarized, supra note 233 , at 1 . The state peualizes wealthy districts that refuse to choose one of the five options. Id. at 2. SB 7 provides that districts that are unable to maintain their 1992-93 level of spending without raising taxes over a specified amount may retain wealth im excess of $\$ 280,000$ per student during a three-year phase-in period. Id. 
al are 1) voluntary consolidation with another district ${ }^{235}$ and 2) detachment and annexation by agreement. ${ }^{236}$ The remaining three clooices, which require voter approval, are 1) the purcliase of attendance credits, ${ }^{237}$ 2) the creation of nonresident student education contracts; ${ }^{238}$ and 3) tax base consolidation. ${ }^{239}$ Witl one exception, all of the higli wealth districts have sent excess funds to the state or other school districts, even though doing so required voter approval..$^{240}$

In addition to capping the amount of wealth per student that a district may liave, SB 7 slightly revised tiers I and II of the foundation program. SB 7 lowered SB 351's basic allotinent under tier I to $\$ 2,300$ per student each year, adjusted by a cost of education index. ${ }^{241}$ To receive tier I funds, a district still inust provide

235. Act of May 30, 1995, ch. 260, sec. 1, §§ 41.031-.034, 1995 Tex. Sess. Law Serv. 2207, 2387 (Vernon) (to be codified at TEx. EDUC. CODE ANN. §§ 41.031-.034). Under this option, the governing boards of two or more districts may consolidate the districts into one with a per pupil wealth of less than $\$ 280,000$. For the first two years after consolidation, the state will provide the consolidated district with the same amount of state funding to which each district would lave been separately entitled. Id.

236. Act of May 30, 1995, ch. 260, sec. 1, §§ 41.061-.065, 1995 Tex. Sess. Law Serv. 2207, 2387-88 (Vernon) (to be codified at TEX. EDUc. CODE ANN. \$§ 41.061-.065). Under this option, the governing boards of two or more districts may agree that territory may be detached froin one district and added to another district if, after the action, each district has a per pupil wealth equal to or less than the equalized wealth level. Id.

237. Act of May 30, 1995, ch. 260, sec. 1, §§ 41.091-.099, 1995 Tex. Sess. Law Serv. 2207, 2388-89 (Vernon) (to be codified at TEX. EDUC. CODE ANN. §§ 41.091-.099). A district may purchase attendance credits from the state to lower its per pupil wealth. Each credit would reduce a district's average daily attendance by one student per year. Average daily attendance for the 1995-96 scltool year is determined by dividing the sum of each day's attendance by the minimum number of school days. Act of May 30, 1995, ch. 260, sec. 1, § 42.005(a-1), 1995 Tex. Sess. Law Serv. 2207, 2397 (Vernon) (to be codified at TEX. EDUC. CODE ANN. \& 42.005(a-1)).

238. Act of May 30, 1995, ch. 260, sec. 1, $\$ \$ 41.121-123,1995$ Tex. Sess. Law Serv. 2207, 2389-90 (Vernon) (to be codified at TEx. EDUC. CODE ANN. \$§ 41.121-.123). Under this plan, a district may contract with another district to educate additional out-ofdistrict students. $S B 7$ Summarized, supra note 233, at 2.

239. Act of May 30, 1995, ch. 260, sec. 1, $\S \$ 41.151-.160,1995$ Tex. Sess. Law Serv. 2207, 2390-91 (Vernon) (to be codified at TEx. EDUC. CODE ANN. §§ 41.151-.160). Two or more districts may agree, with voter approval, to consolidate tax bases as long as the consolidated district has a per student wealth below the equalized wealth level. $S B 7$ Summarized, supra note 233, at 2.

240. Lawrence O. Picus, The Local Impact of School Finance Reform in Four Texas School Districts, 16 EdUC. EVAluATION AND POL'Y ANALYSIS 391, 392 (Winter 1994).

241. TEXAS EDUC. CODE ANN. $\S \S 16.101-2$ (West Supp. 1995), amended by Act of May 30, 1995, ch. 260, sec. 1, \& 42.101, 1995 Tex. Sess. Law Serv. 2207, 2398 (Vernon) (to be codified at TEX. EDUC. CODE ANN. $\$ 42.101$ ). The Texas legislature has subsequently increased the basic allotment to $\$ 2,387$. Act of May 30, 1995, ch. 260 , sec. $1, \S$ 
its "minimum local fund assignment" (LFA) of costs. ${ }^{242}$ The minimum tax rate a district must levy under the LFA for the 1994-95 school year was $\$ .86$ per $\$ 100$ of property value for the prior tax year. ${ }^{243}$ Tier II of the formula, like the older programs, guarantees each district an additional amount for up to $\$ .64$ of tax effort above the LFA. ${ }^{24}$ The revised scheme, however, has lowered the SB 351 guaranteed yield amount to $\$ 20.55$ per student for every cent of taxation over the LFA. ${ }^{245}$

The Edgewood IV court properly noted that although SB 7 lowered the amount of revenue to which poor districts were entitled under SB 351, the SB 7 cap improved the degree of horizontal equity among districts. ${ }^{246}$ The margin, however, remains a wide $\$ 600$ per pupil when districts tax at the full tier II equalization rate. ${ }^{247}$ Like every other revised scheme, SB 7 also promotes vertical equity among districts. Its tier I component provides for add-on weights to account for the additional costs of educating special, gifted, and bilingual students. ${ }^{248}$ The concept of fiscal neutrality, however, is not fully embodied in SB 7's modifications. Because the LFA is a flat rate per $\$ 100$ of taxable property value, the formula does not equalize the tax burden of receiving aid.

Unlike the other states mentioned, Texas improperly failed to require poor districts to spend new aid on curriculum enrichment programs. A study of the local effects of school finance reform under the older SB 351 system shows that absent a nexus between

42.101, 1995 Tex. Sess. Law Serv. 2207, 2398 (Vernon) (to be codified at Tex. Educ. CODE ANN. § 42.101). Under SB 351, however, this amount was $\$ 2,400$ per student. $S B$ 7 Summarized, supra note 233, at 3. Tier I provides for additional funding for special education, gifted students, compensatory, bilingual and vocational education, technology, and transportation. Act of May 30, 1995, ch. 260, sec. 1, $\S \S 42.151-156,1995$ Tex. Sess. Law Serv. 2207, 2399-405 (Vernon) (to be codified at TeX. Educ. CODE ANN. §§ 42.151-.156).

242. Act of May 30, 1995, ch. 260, sec. 1, § 42.252, 1995 Tex. Sess. Law Serv. 2207, 2406-07 (Vernon) (to be codified at TEx. EDUC. CODE ANN. § 42.252).

243. Act of May 30, 1995, ch. 260, sec. 1, $\$ 42.252$ (a), 1995 Tex. Sess. Law Serv. 2207, 2406 (Vernon) (to be codified at TEX. EDUC. CODE ANN. § 42.252(a)); Edgewood IV, 893 S.W.2d 450, 461 (Tex. 1995).

244. Act of May 30, 1995, ch. 260, sec. 1, §§ 42.302-.303, 1995 Tex. Sess. Law Serv. 2207, 2411 (Vernon) (to be codified at TEX. EDUC. CODE ANN. \$§ 42.302-.303).

245. Act of May 30, 1995, ch. 260, sec. 1, § 42.302(a), 1995 Tex. Sess. Law Serv. 2207, 2411 (Vernon) (to be codified at TEX. EDUC. CODE ANN. \$ 42.302(a)); Edgewood $I V, 893$ S.W.2d at 467.

246. Edgewood $I V, 893$ S.W.2d at 464.

247. Id. at $464-65$.

248. See discussion supra note 241 . 
additional aid and substantive educational improvement, poor districts may not use revenue effectively to improve educational quality. ${ }^{249}$ Out of an $\$ 11$ million aid increase, District LM only invested approximately $\$ 2$ inillion in new educational programs. ${ }^{250}$ District $\mathrm{LH}$, the other poor district, received $\$ 10$ million of new funds. ${ }^{251} \mathrm{LH}$ put over $\$ 6$ million of its inoney in a discretionary program for each school. None of the schools used these discretionary funds to make substantive changes to their curricula. ${ }^{252}$ Furthermore, none of the districts used the additional revenue to supplement the textbooks that the Texas Education Agency distributes. ${ }^{253}$

The old SB 351 system also failed to promote curriculum development because it did not require districts to adopt longrange plans for the use of new state aid. In the local district expenditure study, the poor districts that received the greatest amount of funding invested little of their new aid into programs requiring contimuing funding commitments. Poor districts spent most of their inoney on one-time expenditures for facilities instead of improving core academic programs. ${ }^{254}$ Although buildings and facilities enable schools to offer programs, they are not, in and of themselves, elements of a school's core educational agenda. The SB 7 scheine attempts to rectify this shortcoming by requiring each school district to create a long-term district curricula improvement plan. ${ }^{255}$ This change is beneficial because without any state guidance as to how districts should spend aid or a requirement of long-range planning, one cannot predict whether in the future a district will use an aid increase to supplement educational pro-

249. The districts in the study were identified as HHI (high property wealth of $\$ 240,000$ per student, high enrollment of nearly 200,000 students), HM (high property wealth of over $\$ 300,000$ per pupil, medium enrollment of 7,740 students), LH (low property wealth of $\$ 77,031$ per student, high enrollment of 50,036 students), and LM (low property wealth of $\$ 40,871$ per pupil, medium enrollment of 12,970 students). Picus, supra note 240 , at 394.

250. Id. at 398. LM spent most of its new funding, $\$ 8$ million, on constructing a new middle school and upgrading older schools' facilities. Id. District LM also instituted an Instructional Mointoring Program that was designed to improve educational personnel's teaching skills and a parent involvement program. Id.

251. Id.

252. Id. at 403 .

253. Id. at 399.

254. Id. at 403 .

255. Act of May 30, 1995, ch. 260, sec. 1, § 11.252, 1995 Tex. Sess. Law Serv. 2207, 2232-33 (Vernon) (to be codified at TEX. EDUC. CODE ANN. § 11.252). 
grams. However, unlike New Jersey's system, SB 7 does not appear to make districts justify expenditures to the state.

Moreover, despite new long-range planning requirements, poor districts could refrain from expanding their curricula because of the Texas schemes' historical lack of funding stability. For exainple, in May of 1992, former Governor Richards and the legislative leadership informed schools that there would be no new education revenue for fiscal year 1992-93. ${ }^{256}$ A perceived lack of state commitment to funding education would cause districts to refrain from making educational improvements, such as the creation of new courses or remedial programs, that would involve long-term costs. 257

Although the SB 7 formula lacks several elements that could encourage curriculum enrichment, it appropriately provides for extensive accountability mechanisms. For exannle, districts must develop end-of-course exams ${ }^{258}$ and publish an annual canupus report card that describes students' performance. ${ }^{259}$ In addition, the Texas Board of Education must adopt a set of academic excellence indicators that measure the quality of learning. ${ }^{260}$ Although these accountability methods may help districts assess students' overall achievement, the mechamsms cannot ascertain which additional aid programs effectively enhance students' educations. The acconntability mecharnsms also fail to require educational development as a condition to receiving aid. Because the Texas scheme lacks the requisite state oversight of districts' expenditures, the revised formula cannot maximize educational improvement in poor school districts.

256. Picus, supra note 240 , at 397.

257. Students in poor districts are not the only ones to suffer under a system without funding stability. Wealthy districts, which typically have been the most innovative in educational offerings, may make cuts because of instability and decreasing aid receipts. For example, District HH had to scale back and defer several educational enhancement programs, including a plan to develop partnerships with businesses and other social service agencies. Id. at 398 .

258. Act of May 30, 1995, ch. 260, sec. 1, § 39.023, 1995 Tex. Sess. Law. Serv. 2207, 2370-71 (Vernon) (to be codified at TEX. EDUC. CODE ANN. $\$ 39.023$ ).

259. Act of May 30, 1995, ch. 260, sec. 1, §§ 39.051-.053, 1995 Tex. Sess. Law Serv. 2207, 2374-75 (Vernon) (to be codified at TEX. EDUC. CODE ANN. \$§ 39.051-.053).

260. Act of May 30, 1995, ch. 260, sec. 1, § 39.051 . 


\section{CONCLUSION}

Finance schemes that rely primarily on property taxes to fund education create wealth-based disparities in educational opportunities. The high courts of Kentucky, Massachusetts, New Jersey, Tennessee, and Texas recently have used state constitutional grounds to invalidate property-tax funding systems. Although legislative responses to these decisions have given poor schools additional funding, the new systems still fail to provide poor schools with equal access to state aid.

An analysis of revised funding formulas reveals that the most effective elements in ensuring educational equality are horizontal equity, vertical equity, and fiscal neutrahity. Spending caps are one way that states have created horizontal equity. For example, withm four years of Kentucky's institution of a spending cap, expenditure disparities decreased from almost $69 \%$ to less than $17 \%$. Similarly, Texas has progressed towards equalization of school districts' revenues by limiting a school district's taxable property value.

Fiscal neutrality is also a necessary component. Each revised system appropriately includes fiscal neutrality because the new formulas account for the extra costs of educating special students. However, none of the states in this study appear to base special student funding on empirical data that reflect the actual costs of educating them. Because poor districts typically have the greatest concentration of special-needs students, the revised funding schemes contimue to leave poor districts short-changed. To be fiscally neutral, states must account for income differences among districts when determining how much inoney a poor district must raise to qualify for state aid. Systems that have a flat minimunı contribution irrespective of wealth still impermissibly condition aid on a district's ability to tax.

To enrich the quality of education for poor students, states' funding scheines must also induce districts to improve and expand upon their core curricula and inplement accountability mechamisms. Empirical evidence illustrates that withholding total local discretion and creating mcentives such as broad-based assessment, long-range planning requirements, and specific program mandates successfully encourage curriculunı inprovement. On the other hand, experience shows that states that do not inplement such 
measures fail to improve the quality of education. To ensure equal educational opportunity, states must take on a more regulatory role in education and school districts need to relinquish a degree of local academic control. 